\title{
The seasonal planktonic cycle in coastal waters of the Canary Islands*
}

\author{
JAVIER ARÍSTEGUI, SANTIAGO HERNÁNDEZ-LEÓN, MARÍA F. MONTERO \\ and MAY GÓMEZ
}

Biological Oceanography Laboratory, Facultad de Ciencias del Mar, Campus Universitario de Tafira, 35017 Las Palmas de Gran Canaria, Spain. E-mail: javier.aristegui@biologia.ulpgc.es

\begin{abstract}
SUMMARY: The short-term temporal variation in the phytoplankton and mesozooplankton cycles was studied in a coastal area off east Gran Canaria Island. A small phytoplankton bloom, split into two peaks, appeared during late winter (end of February and March), coinciding with the lowest temperatures in the water column. A clear inverse relationship was observed between the biomasses in mesozooplankton and phytoplankton during the bloom period. The peaks in primary production and phytoplankton biomass were uncoupled in time, suggesting that biomass could depend on consumer control (grazing), and primary production on resource control (nutrients). Mesozooplankton grazing represented less than $20 \%$ of the primary production, an indication that small zooplankton and protozoans controlled the phytoplankton populations, dominated by picoplanktonic cells ( $>60 \%$ of the primary production). The ratio between depth-integrated primary production and community respiration $(\mathrm{P} / \mathrm{R})$ covaried with primary production $(\mathrm{P})$, showing that changes in $\mathrm{P}$ control the trophic status of the system. At $\mathrm{P}>400 \mathrm{mgC} \mathrm{m}^{-2} \mathrm{day}^{-1}$ the $\mathrm{P} / \mathrm{R}$ ratio is $>1$, switching the system from heterotrophy to autotrophy, a situation that takes place during the phytoplankton growth period.
\end{abstract}

Key words: plankton cycles, primary production, plankton respiration, mesozooplankton ingestion, P/R ratio, Canary Islands.

\section{INTRODUCTION}

The temporal variability of planktonic cycles in subtropical waters is largely unknown, in comparison with temperate regions where many detailed studies on seasonal cycles have been done (e.g., Sverdrup, 1953; Purdie, 1996). Moreover, since subtropical regions have been frequently regarded as the least biologically variable waters, the few studies carried out in these regions (Menzel and Ryther, 1960; Jitts, 1969; Sournia, 1969; Owen and Zeitzschel, 1970; Bienfang et al., 1984) were

\footnotetext{
*Received February 21, 2000. Accepted September 3, 2000.
}

designed with a monthly sampling strategy that barely represented the true variability in the structure and metabolism of planktonic communities. The Canaries region has not been an exception. Past studies (De León and Braun, 1973; Braun, 1980) portray the surface waters as oligotrophic, with low variability in plankton biomass and productivity, presumably caused by the stability of the physical environment.

Recent work has shown, however, that plankton communities in the Canaries region may be influenced by mesoscale variability. Island eddies may pump nutrients into the surface waters (Arístegui et al., 1994; 1997); wind shearing in the boundaries of 
the islands increases vertical mixing along the coast (Arístegui et al., 1989); and upwelling filaments may export organic matter from the African coast into the surface Canary waters (Barton et al., 1998). Nevertheless, in spite of this variability, the region as a whole, and particularly the waters less influenced by island effects, present low water-column integrated values of phytoplankton biomass and productivity during most of the year (De León and Braun, 1973; Braun, 1980; Arístegui, 1990).

The surface waters around the Canary Islands, like other subtropical seas, are affected by strong heating throughout the year, which promotes the development of a quasi-permanent sharp thermocline. This restricts the vertical flux of nutrients from deep waters to the euphotic zone, limiting phytoplankton growth. The thermocline weakens during winter time, as the result of surface cooling, the mixed layer reaching its maximum penetration depth in March (Barton et al., 1998). The thermocline begins to reform in April-May, leading to the more common situation of a surface euphotic zone depleted of inorganic nutrients. It is, therefore, during the short mixing period when phytoplankton can grow faster and build up a biomass pool ("phytoplankton bloom"), provided that the cellular growth rate is higher than the grazing rate.

The sparse seasonal studies in the region describe peaks in chlorophyll and primary production during late winter. These maxima are significantly higher than the annual means (Braun and Real, 1984), but much lower than the maxima observed in temperate waters during the spring bloom (e.g., Harvey et, al., 1935; Sverdrup, 1953). Whether these values are the result of the injection of nutrients into the impoverished euphotic zone (resource control), the effect of the grazing pressure (consumer control), or both, is still an unresolved question.

Here we present the study of a seasonal planktonic cycle in a coastal area, close to the island slope, far from the influence of wind shearing effects. Contrary to other coastal regions with more extensive shelves, the maximum productivity and chlorophyll values in coastal waters of the Canary Islands do not differ significantly from the open ocean values (Braun and Real, 1984), except in those places where strong mixing events take place (Arístegui et al., 1989). The narrow shelf around the islands (few miles in extension) prevents coastal waters from behaving as an independent system regarding the oceanic domain. Rather, coastal planktonic cycles seem to depend tightly on the structure and stability of the water column in the nearby ocean. The aim of this work was two-fold. First, to study for the first time the weekly variability of the phyto- and mesozooplanktonic cycles during the late winter bloom to infer the degree of coupling between the two communities. Second, to quantify the grazing impact of mesozooplankton on the phytoplankton biomass and productivity.

\section{MATERIAL AND METHODS}

A single station on the eastern shelf of the island (Fig. 1) was sampled for plankton productivity and biomass studies from November 1988 to June 1989, with a time spacing of one to three weeks, the closest sampling being during the most productive period (February and March). Water samples were collected in Niskin bottles from surface to the bottom $(40 \mathrm{~m})$. From each bottle, subsamples were drawn for analysis of chlorophyll $a$ (up to 4 litres), primary production ( $125 \mathrm{ml}$ per incubation bottle) and the respiratory activity of the electron transport system (ETS) in microplankton (5 litres). Temperature was measured in the water column by means of reversing thermometers.

Chlorophyll $a$ was estimated by the absorbance method, using the spectrophotometric equations of Jeffrey and Humphreys, as described in Parsons et al. (1984). Primary production was measured using the ${ }^{14} \mathrm{C}$ method of Steeman Nielsen (1952). After adding ca. $5 \mu \mathrm{Ci} \mathrm{H}{ }_{2}{ }^{14} \mathrm{C}$, duplicate clear and dark borosilicate bottles were incubated in situ at midday for 2 to 4 hours at the same vertical depths where water samples had been obtained in the cast. Incubations were

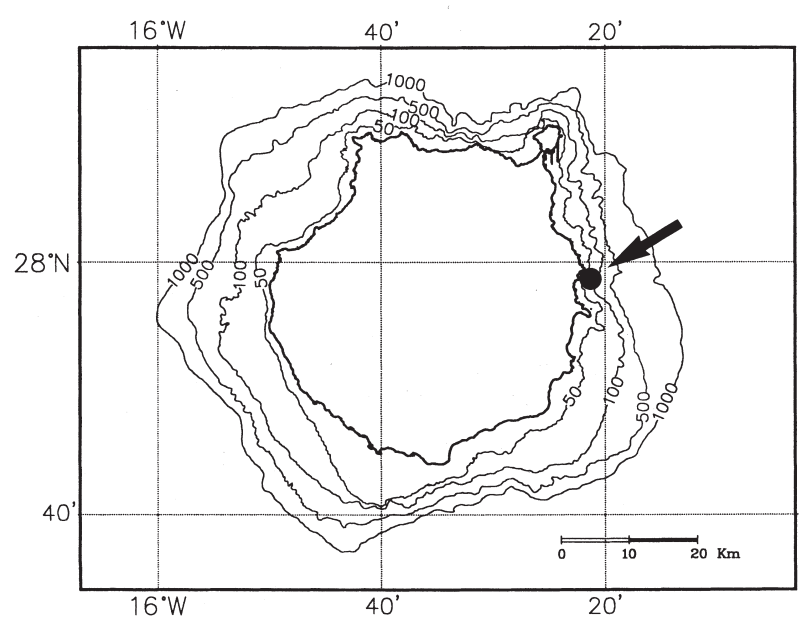

FIG. 1. - Map of Gran Canaria Island with coastal bathymetry. The surveyed station (black circle) is pointed by an arrow 
terminated by gentle filtration of replicate samples on $0.45 \mu \mathrm{m} \mathrm{GF} / \mathrm{F}$ glassfiber filters and $2 \mu \mathrm{m}$ Nuclepore polycarbonate filters. Filters were dried overnight, fumed for one minute over concentrated $\mathrm{HCl}$ to remove dissolved ${ }^{14} \mathrm{C}$, placed in $15 \mathrm{ml}$ of scintillation cocktail (Aquasol-2), and assayed in a liquid scintillation counter with an external standard.

Mesozooplankton was caught in one vertical haul (from 0-40 m) using a WP-2 double net, a version of the standard WP-2 net (Unesco, 1968). One of the samples was used for taxonomical studies of the main zooplankton groups. The other sample was frozen in liquid nitrogen until analysis in the laboratory, to determine biomass as proteins. Proteins were assayed following the method of Lowry et al. (1951), using Bovine Serum Albumine (BSA) as standard. Mesozooplankton ingestion was determined from an empirical relationship obtained between dry weight and proteins for mesozooplankton populations in the Canary waters (Hernández León, unpublished data), considering that carbon biomass represents $40 \%$ of dry weight.

ETS activity for microplankton (organisms $<200$ $\mu \mathrm{m})$ was determined in accordance with Packard (1969) and Kenner and Ahmed (1975). Details of the procedures are described in Arístegui and Mon-

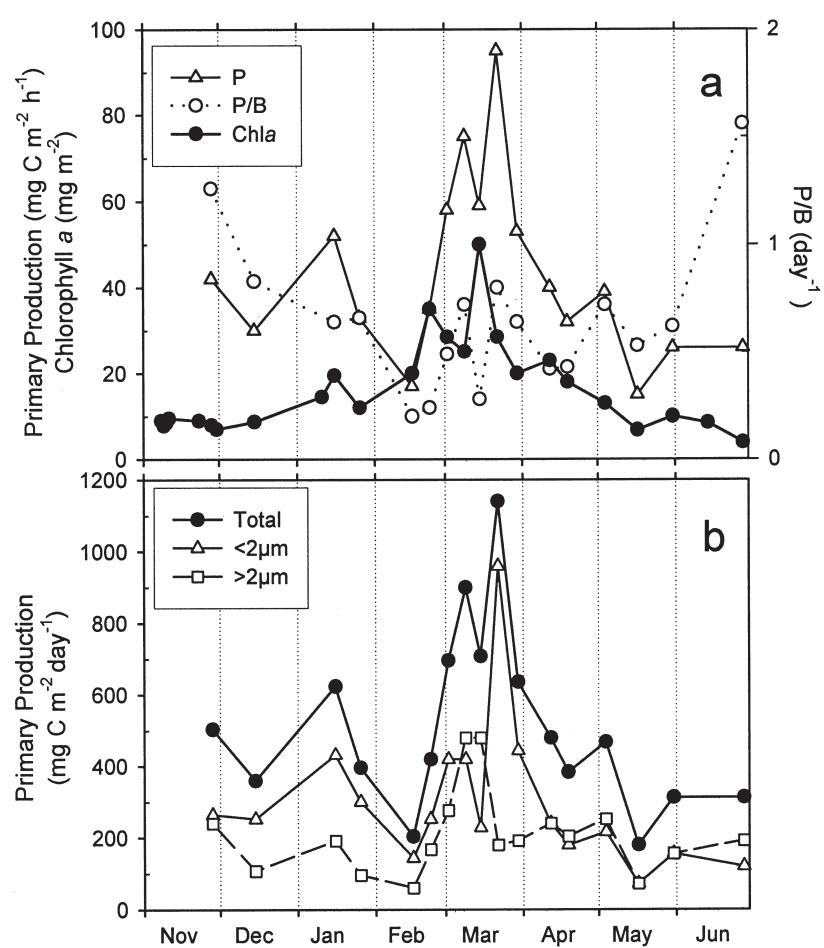

FIG. 2. - Temporal distribution of (a) depth-integrated primary production $(\mathrm{P})$, chlorophyll $a(\mathrm{Chl} a)$ and the phytoplankton primary production/carbon biomass ratio $(\mathrm{P} / \mathrm{B})$, and (b) size-fractionated ( $>$ and $<2 \mu \mathrm{m}$ ) primary production. Phytoplankton biomass (B) was calculated from Chla using a carbon/chlorophyll ratio of 50. tero (1993). Community respiration was estimated using an average empirical R/ETS ratio of 0.5 obtained for coastal Canary waters (Arístegui and Montero, unpublished data).

\section{RESULTS}

A small chlorophyll bloom, split into two peaks, was observed from the end of February to mid March (Fig. 2a). Two peaks in primary production were also observed during the same period, although uncoupled in time from the chlorophyll maxima (Fig. 2a). Increases in primary production coincided with demises in chlorophyll, suggesting that other factors beside growth rate control the phytoplankton biomass distribution. The first peak in production occurred the first week of March and resulted from the activity of both small $(<2 \mu \mathrm{m})$ and large $(>2 \mu \mathrm{m})$ cells (Fig. 2b). The second, and largest, peak occurred at the end of March, being almost due to small cells.

The mesozooplankton biomass distribution, did not show a statistically significant relationship with chlorophyll, considering the whole period of study. Nevertheless, Figure 3a illustrates a clear inverse

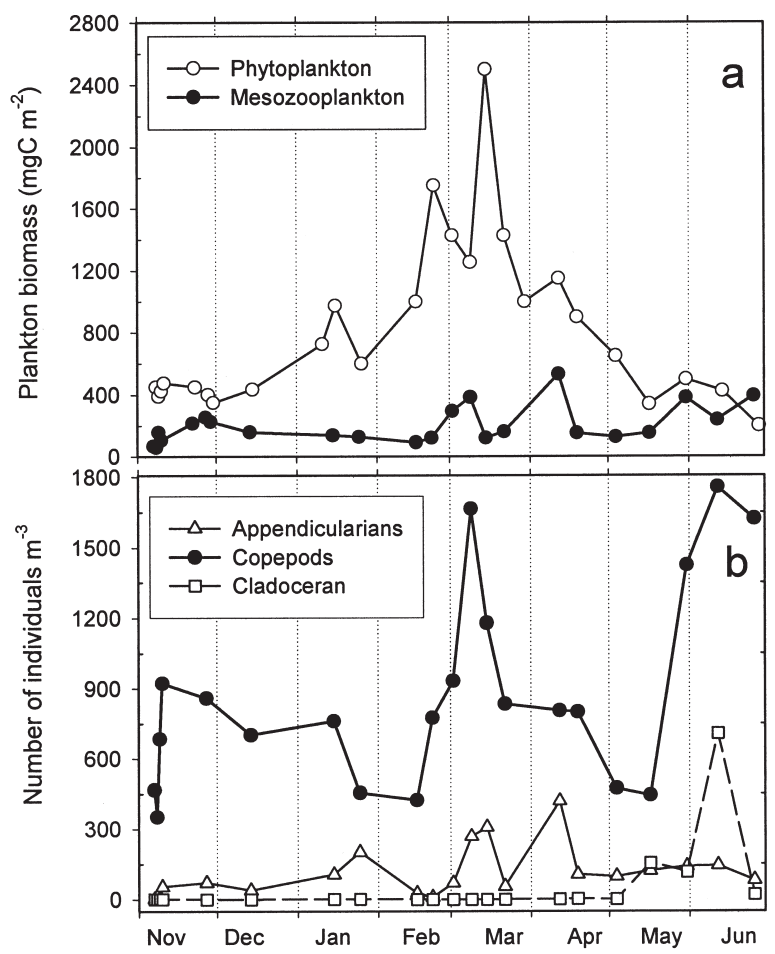

FIG. 3. - Temporal distribution of (a) depth-integrated phytoplankton and mesozooplankton biomasses (see the text for conversions to carbon units), and (b) abundances per average volume unit of the main mesozooplankton groups (appendicularians, copepods and cladoceran). 

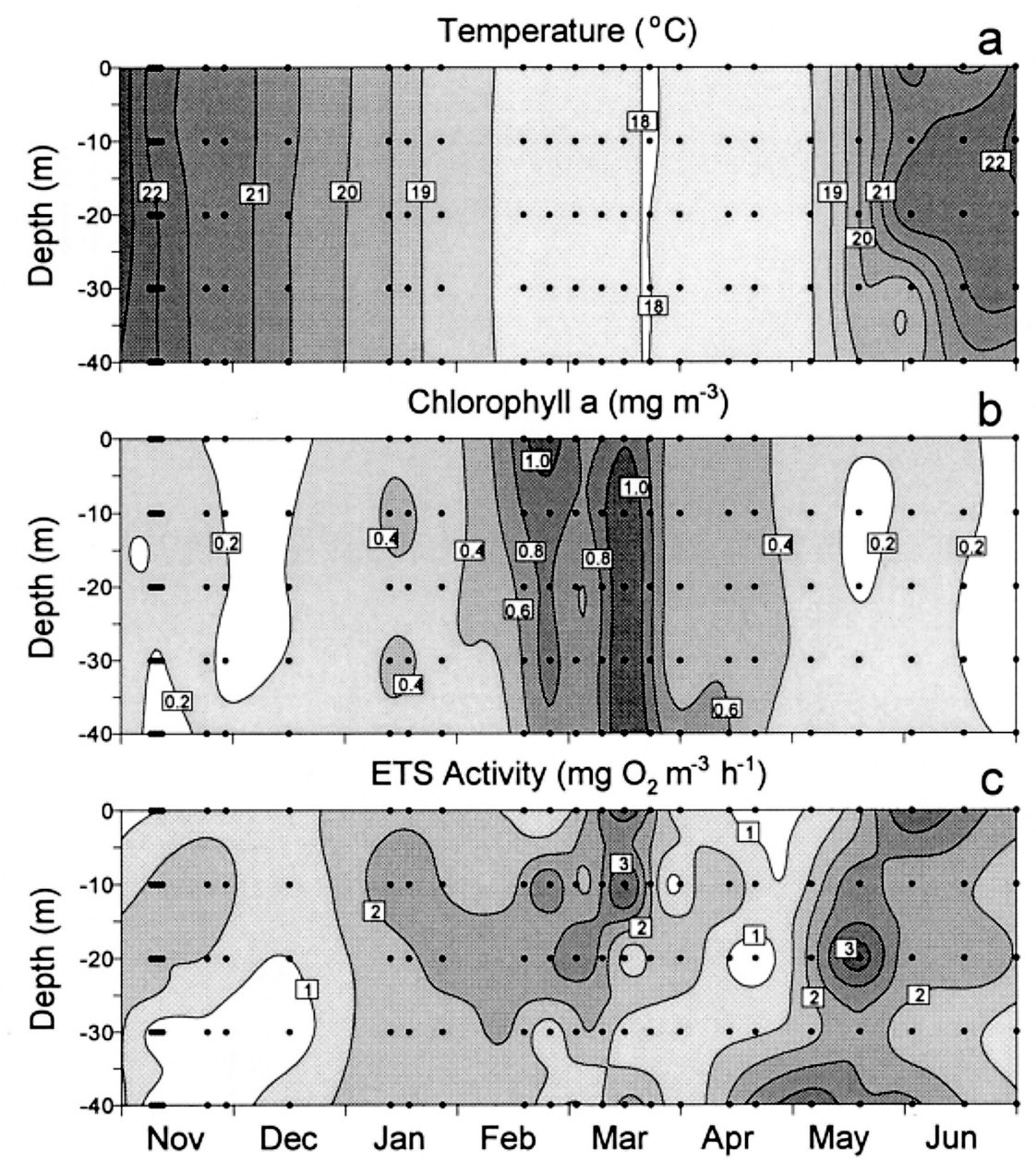

FIG. 4. - Vertical distribution of (a) temperature (b) chlorophyll $a$ and (c) the respiratory activity of the electron transport system (ETS) in microplankton $(<200 \mu \mathrm{m})$. Black dots represent sampling depths.

relationship between the peaks in mesozooplankton and phytoplankton biomass during the bloom period (end of February to beginning of April). Copepods the most representative zooplankton group- peaked during the second week of March, at the same time as chlorophyll dropped (Fig. 3). The increase in chlorophyll the week after -reaching to the maximum values of the cycle- was matched by both a drop in copepod numbers (which are also smaller in size) and in total mesozooplankton biomass. A new peak in mesozooplankton biomass was achieved during the second week of April, caused this time by the presence of large copepods and a relative maximum in apendicularians, although chlorophyll values did not change as sharply as in the former occasions. The end of May and June were characterized by low values in primary production and chlorophyll but relatively high mesozooplankton biomass and number of individuals (mainly copepods and cladocerans; Fig. 3b), an indication that other sources than phytoplankton represent the main diet of mesozooplankton.
The respiratory ETS activity in microplankton increased during mid March, coinciding with the lowest temperatures (Fig. 4a) and the outburst of the phytoplankton bloom (Fig. 4b). Nevertheless, the highest integrated ETS activity values in the water column were observed in May and June (Fig. 4c), when chlorophyll was low, presumably due to the metabolism of microheterotrophs.

\section{DISCUSSION}

\section{Phytoplankton and zooplankton cycles}

The timing of the phytoplankton bloom coincides with other reported maxima in coastal and oceanic waters around the islands (De León and Braun, 1973; Braun and Real, 1984). It results from the erosion of the open ocean thermocline, due to the cooling of surface waters, enhancing vertical mixing and the injection of new nutrients from the 
aphotic zone into the surface layers. Due to the narrow shelf of the islands (few miles in extension), the input of nutrients affects coastal waters as well, and hence the bloom is produced at the same time as in the ocean.

The magnitude and extension of the bloom are smaller than in coastal temperate waters, in spite of the four-fold increase in biomass (maximum $50 \mathrm{mg}$ Chl $a \mathrm{~m}^{-2}$ ) with respect to the mean annual value (16 $\pm 10 \mathrm{mgChl} a \mathrm{~m}^{-2}$ ), which is roughly the same in open ocean waters (Montero, 1993). The peak in primary production $\left(>1 \mathrm{grC} \mathrm{m}^{-2}\right.$ day $\left.^{-1}\right)$ is also similar to the highest productivity values found in the open ocean associated with mesoscale features where nutrient input takes place (Basterretxea, 1994). However, the mean value $\left(513 \pm 249 \mathrm{mgC} \mathrm{m}^{-2}\right.$ day $\left.{ }^{1}\right)$ in the coast contrasts with the lower primary production ( down to $50 \mathrm{mgC} \mathrm{m}^{-2}$ day $^{-1}$ ) measured during periods of thermal stratification in the ocean. These are caused by an extended nutrient limitation to phytoplankton cells living at saturating light intensities, an unlikely situation in coastal populations. Indeed, production / biomass $(\mathrm{P} / \mathrm{B})$ ratios are high during the whole period of this study (average value 0.65 day $^{-1}$ ) (Fig. 2a), an indication that coastal phytoplankton is not severely nutrient limited. Small but constant inputs of new nutrients (sensu Dugdale and Goering, 1967) from land sources or the bottom of the shelf would be enough to maintain a moderate production year round.

Beside its magnitude, one of the main differences between the phytoplankton bloom in temperate and subtropical waters is the way it is produced. In temperate waters, the spring bloom starts after thermal stratification of the nutrient-replenished surface water, when the critical depth gets shallower than the mixing zone (Sverdrup, 1953). In subtropical waters, the bloom starts when the thermocline is disrupted and new nutrients are made available into the nutrient-depleted euphotic zone. This occurs at the end of winter, when surface temperature drops and the thermal stratification is broken. The fuelling by nutrients affects not only to the surface waters of the open ocean, but also to coastal waters, allowing the development of phytoplankton species which grow better under high nutrient concentrations.

No phytoplankton taxonomic analyses were performed during this study. Nevertheless, it has been observed elsewhere (Ojeda, 1998) that a short-lived peak in diatoms is produced when the surface temperature drops to its lowest values (generally mid March), being rapidly substituted by smaller cells, which may peak again. Thus, the highest peak in chlorophyll in mid March, which coincides with a peak in primary production of cells $>2 \mu \mathrm{m}$ (Fig. 2), must be due in large part to diatoms. Conversely, the highest peak in primary production at the end of March, coinciding with a decrease in chlorophyll, is mainly due to cells $<2 \mu \mathrm{m}$, presumably with a high carbon to chlorophyll ratio.

In temperate waters the fate of the diatom bloom (with more than 100 cells $/ \mathrm{ml}$ ) appears to be total sedimentation in most of the situations (Purdie, 1996), since the delay between phytoplankton and zooplankton cycles allows cells to grow and sink down, before the grazing pressure is effective. Evans and Parslow (1985), simulating an annual cycle in temperate waters, found that the depth of the mixed layer during the preceding winter was critical for the development of the spring bloom. When a deep mixed layer is formed in winter time, algal growth is reduced, caused by the low average underwater irradiance, and zooplankton is therefore scarce.

In the Canaries region, however, as well as in other subtropical waters, the mixed layer is generally shallower than the critical depth. The smoother seasonal temperature changes year-round and the usually low concentration of nutrients in surface waters favours the presence of small nano and picoplanktonic cells with rapid turnover times, and a tight coupling between production, consumption, and nutrient regeneration. Microplankton play a key role not only controlling the growth of small cells via the grazing effect, but also assessing the direct supply of mineral nutrients for phytoplankton and dissolved organic matter for bacteria (Banse, 1992)

Past studies in waters around the Canary Islands identified one or two biomass peaks during the annual mesozooplankton cycle, which are not always coincident with peaks in number of individuals (Fernández de Puelles and García Braun, 1989; 1996). The low temporal resolution in these samplings (generally monthly) failed to describe the degree of coupling between phytoplankton and mesozooplankton, observed in this study at shorter temporal scales. Peaks in mesozooplankton biomass should be produced by either an increase in the number or by an increase in the size of the individuals. In both situations the increase would affect directly or indirectly the biomass of phytoplankton; i.e. mesozooplankton can graze directly on large phytoplankton cells, as well as ingest protozooans which in turn graze on the smallest phytoplankton. 
In our study, an inverse relationship is evident between the peaks of mesozooplankton and phytoplankton during the bloom season (Fig. 3a). A similar relationship was obtained for coastal waters around the Canary Islands by Arístegui (1990), who suggested that mesozooplankton could control the phytoplankton bloom.

\section{Biomass distribution and zooplankton grazing impact}

The phytoplankton organic carbon (POC) integrated during the whole study amounts to $172 \mathrm{gC} \mathrm{m}^{-}$ 2 (using a C/Chla ratio of 50), with a daily mean of $808 \pm 542 \mathrm{mgC} \mathrm{m}^{-2}$. This value is as low as the oceanic mean in the Canary region (Montero, 1993), but it represents about four times the mesozooplankton organic carbon $\left(\mathrm{MOC}=217 \pm 130 \mathrm{mgC} \mathrm{m}^{-2}\right.$ day $^{-1}$ ). The difference would be even larger if we considered a higher $\mathrm{C} / \mathrm{Chl} a$ conversion factor, which could be more representative of oligotrophic systems where autotrophic picoplankton dominate (e.g., Cullen et al., 1992; Verity et al., 1996).

A relative low mesozooplankton / phytoplankton biomass (MOC/POC) ratio, like the one found in our study (mean daily value: $0.2 \pm 0.2$ ), characterise oligotrophic ecosystems (Gasol et al. 1997). In these environments, autotrophs are dominated by picoplankton and mesozooplankton by copepods. Only a small percentage of the primary production (larger cells) is directly transferred to mesozooplankton herbivores. The larger part is channelled through protozoa and bacteria, which represent about $75 \%$ of the heterotrophic biomass, and form a larger biomass pool than the phytoplankton (Gasol et al. 1997).

In the Canary waters, bacterial organic carbon (BOC) is always greater than POC (BOC/POC ranges between 1.5 and 1.9; Ballesteros, 1994), a common situation in warm oligotrohic seas (Fuhrman et al., 1989; Cho and Azam, 1990). Moreover, heterotrophic flagellates are more abundant than phytoflagellates (Ballesteros, 1994), and nauplii and copepodites are as important or more in terms of biomass than mesozooplankton (Fernández de Puelles and García Braun, 1996). All these characteristics portray a scenario of an unproductive region where fast growing small phyto and zooplankton species dominate biomass and production during most of the year.

The integrated primary production overall was $97 \mathrm{gC} \mathrm{m}^{-2}$, with a mean value of $513 \pm 249 \mathrm{mgC} \mathrm{m}^{-2}$

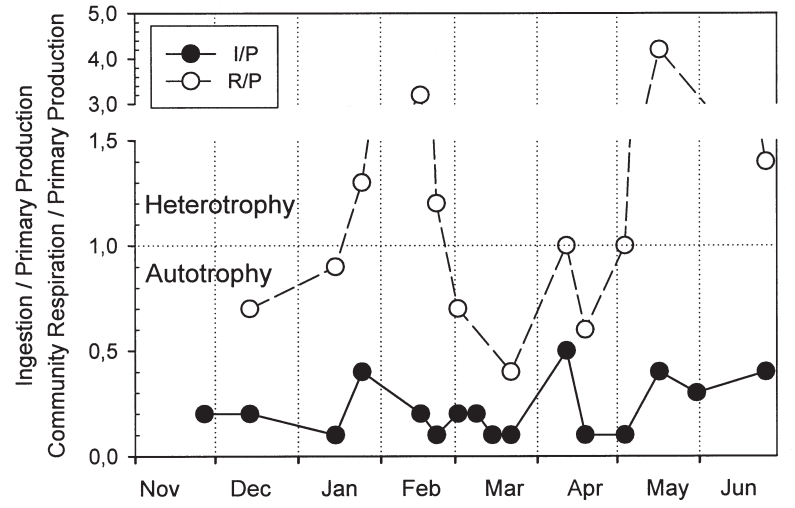

FIG. 5. - Temporal distribution of the ratios of depth-integrated mesozooplankton ingestion / primary production (I/P) and community respiration / primary production $(\mathrm{R} / \mathrm{P})$. Notice the shift from heterotrophy to autotrophy $(\mathrm{R} / \mathrm{P}<1)$ during the phytoplankton growth period.

day $^{-1}$. Sixty percent of this primary production is due to cells $<2 \mu \mathrm{m}$, an indication that protozoan grazing, microbial loop processes and regenerated production must predominate over new production and direct transfer of biomass to upper trophic levels. Indeed, ingestion by mesozooplankton was estimated as $20 \mathrm{gC} \mathrm{m}^{-2}$. Considering that all the food ingested was phytoplankton, grazing by mesozooplankton would roughly represent $20 \%$ of the primary production (Fig. 5). However, since mesozooplankton feeds also on small microheterotrophs its grazing impact will be obviously lower. In any case, assuming that most of the net primary production is grazed, it is evident that microzooplankton (protozooans and the smallest metazooans) are the main components of the trophic web, controlling more than $80 \%$ of the primary production.

\section{Autotrophy versus heterotrophy}

The primary production / community respiration $(\mathrm{P} / \mathrm{R})$ ratio covaries with primary production $(\mathrm{P})$, showing a highly significant positive relationship (Fig. 6). At $\mathrm{P}$ values $>400 \mathrm{mgC} \mathrm{m}{ }^{-2}$ day $^{-1}$, the $\mathrm{P} / \mathrm{R}$ ratio is $>1$, switching the system from heterotrophy to autotrophy. This indicates that, albeit community respiratory activity is variable throughout the period of study (Fig. 4c), changes in P will mainly control the trophic status of the ecosystem. The system ranges from strong heterotrophy, before and after the bloom period, to a moderate autotrophy when phytoplankton and zooplankton peak (Fig. 5). This change in the trophic status of the system is not reflected in the MOC/POC ratio, which is always $<0.5$. It seems therefore, that the smaller $(<200 \mu \mathrm{m})$ 


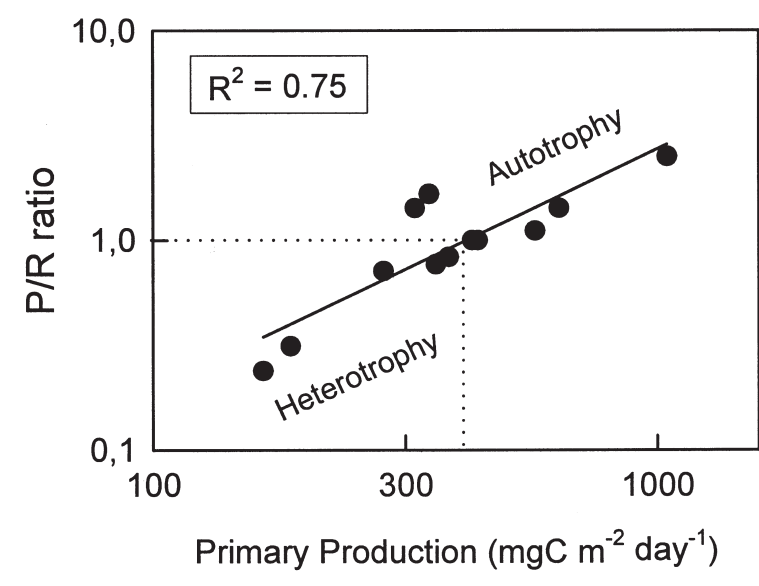

FIG. 6. - Relationship between the ratio of depth-integrated primary production and community respiration $(\mathrm{P} / \mathrm{R})$ and the depth-integrated primary production. The line represents the fitted regression equation,

$\log \mathrm{P} / \mathrm{R}=-3.0+1.14 \log \mathrm{P}\left(\mathrm{R}^{2}=0.75, \mathrm{P}<0.0001, \mathrm{~N}=12\right)$.

heterotrophic components have a larger influence in the ratio between autotrophic and heterotrophic biomasses.

The close coupling between POC and MOC during the bloom period -even when mesozooplankton grazing represents only a small percentage of the primary production- suggests that phytoplankton biomass depends mainly on a consumer control. This control would be basically through the microplankton, although mesozooplankton would graze on large phytoplankton cells during the bloom period as well as on protozoans.

Primary production, however, could depend on resource control at least at the start of the bloom period. This would explain the shift from heterotrophy to autotrophy in the metabolic P/R ratios (Fig. 5). The coincidence between the phytoplankton growth period and the lower water temperatures indicates that when vertical mixing increases there is input of new nutrients necessary for the onset of the bloom. According to Banse (1992) a bloom in this way can terminate by grazing instead of nutrient exhaustion. This may be the case observed in Figure 2a where phytoplankton biomass drops in the third week of March, while primary production achieves its highest rate.

The data shown in this study strongly support the view that phytoplankton biomass is tightly controlled by the smallest components of the consumers' community. Nevertheless the switch between heterotrophy and autotrophy in the $P / R$ ratio may parallel also a change in the community structure. Therefore, a future work on seasonal planktonic cycles in the Canaries region must include the microplankton components of the trophic web to fully understand the coupling between autotrophs and heterotrophs.

\section{ACKNOWLEDGEMENTS}

We would like to thank all the colleagues from the Biological Oceanography Group that contributed to the field work. We also thank to Fernando Bordes for providing Figure 1. This research was funded by the project 82/22.04.85 (GAC).

\section{REFERENCES}

Arístegui, J. - 1990. La distribución de la clorofila $a$ en aguas de Canarias. Bol. Inst. Esp. Ocean., 6(2): 61-72.

Arístegui, J. and M.F. Montero. - 1993. The relationship between community respiration and ETS activity in the ocean. J. Plankton Res., 17: 1565-1573.

Arístegui, J., S. Hernández León, M. Gómez, L. Medina, A. Ojeda and S. Torres. - 1989. Influence of the north trade winds on the biomass and production of neritic plankton in Gran Canaria. In: J.D. Ros (ed.), Topics in Marine Biology. Sci. Mar., 53: 223-229.

Arístegui, J., P. Sangrá, S. Hernández León, M. Cantón, A. Hernández Guerra and J.L. Kerling. - 1994. Island-induced eddies in the Canary Islands. Deep-Sea Res., 41: 1509-1525.

Arístegui, J., P. Tett, A. Hernández Guerra, G. Basterretxea, M.F. Montero, K. Wild, P. Sangrá, S. Hernández León, M. Cantón, J.A. García Braun, M. Pacheco and E.D. Barton. - 1997. The influence of island generated eddies on chlorophyll distribution: a study of mesoscale variation around Gran Canaria. Deep-Sea Res., 44: 71-96.

Ballesteros, S. - 1994. Influencia de las estructuras mesoescalares sobre la distribución y abundancia de bacterias y cianobacterias en aguas de Canarias. Ph.D. thesis. Univ. Las Palmas de Gran Canaria, 153 pp.

Banse, K. - 1992. Grazing, temporal changes of phytoplankton concentrations, and the microbial loop in the open sea. In: P.G. Falkowski and A.D. Woodhead (eds), Primary Productivity and Biogeochemical Cycles in the Sea, pp. 409-440. Plenum Press, New York.

Barton, E.D, J. Arístegui, P. Tett, M. Cantón, J. García Braun, S. Hernández León, L. Nykjaer, C. Almeida, J. Almunia, S. Ballesteros, G. Basterretxea, J. Escánez, L. García Weill, A. Hernández Guerra, F. López Laatzen, R. Molina, M.F. Montero, E. Navarro Pérez, J.M. Rodríguez Pérez, K. van Lenning, H. Vélez and K. Wild. - 1998. The transition zone of the Canary Current upwelling region. Prog. Oceanogr. 41(4): 455-504.

Basterretxea, G. - 1994. Influencia de las estructuras oceanográficas mesoescalares sobre la producción primaria en la región canaria. Ph.D. thesis, Univ. Las Palmas de Gran Canaria, 113 pp.

Bienfang, P.K., J.P. Spyzer, M.Y. Okamoto and E.K. Noda. - 1984. Temporal and spatial variability of phytoplankton in a subtropical ecosystem. Limnol. Oceanogr., 29: 527-539.

Braun, J.G. - 1980. Estudios de producción en aguas de las Islas Canarias. I, hidrografía, nutrientes y producción primaria. Bol. Inst. Esp. Ocean., 285: 149-154.

Braun, J.G. and F. Real. - 1984. Estudios de producción en la bahía de Antequera: una comparación con aguas oceánicas. Bol. Inst. Esp. Ocean., 291: 97-105.

Cho, B.C. and F. Azam. - 1990. Biogeochemical significance of bacterial biomass in the ocean's euphotic zone. Mar. Ecol. Prog. Ser., 63: 253-259

Cullen, J.J., X. Yang and H.L. MacIntyre. - 1992. Nutrient limitation of marine photosynthesis. In: P.G. Falkowski and A.D. Woodhead (eds), Primary Productivity and Biogeochemical Cycles in the Sea, pp. 69-88. Plenum Press, New York. 
De León, A.R. and J.G. Braun. - 1973. Ciclo anual de la produccion primaria y su relación con los nutrientes en aguas Canarias. Bol. Inst. Esp. Ocean., 167: 1-24.

Dugdale, R.C. and J.J. Goering. - 1967. Uptake of new and regenerated forms of nitrogen in primary productivity. Limnol. Oceanogr., 12: 196-206

Evans, G.T. and J.S. Parslow. - 1985. A model of annual plankton cycles. Biol. Oceanogr., 3: 327.

Fernández de Puelles, M.L. and J.A. García Braun. - 1989. Dinámica de las comunidades planctónicas en una zona del Atlántico Subtropical (Isla de Tenerife). Bol. Inst. Esp. Ocean., 5(2): 87-100.

Fernández de Puelles, M.L. and J.A. García Braun. - 1996. Micro and mesozooplankton in Canarian waters. In: O. Llinás, J.A. González and M.J. Rueda (eds.), Oceanography and marine resources in the Eastern Central Atlantic, pp. 69-91. Gobierno de Canarias.

Fuhrman, J.A., T.D. Sleeter, C.A. Carlson and L.M. Proctor. 1989. Dominance of bacterial biomass in the Sargasso Sea and its ecological implications. Mar. Ecol. Prog. Ser., 57: 207-217.

Gasol, J.M., P.A. del Giorgio and C.M. Duarte. - 1997. Biomass distribution in marine planktonic communities. Limnol. Oceanogr., 42: 1353-1363.

Harvey, W.H., L.N. Cooper, M.V. Lebour and F.S. Russell. - 1935. Plankton production and its control. J. Mar. Biol. Ass. U.K., 20: 407-441.

Jitts, J.R. - 1969. Seasonal variations in the Indian Ocean along $110^{\circ}$ E. 4. Primary production. Aust. J. Mar. Freshwater Res., 20: $65-75$.

Kenner, R.A. and S.I. Ahmed. - 1975. Measurements of electron transport activities in marine phytoplankton. Mar. Biol., 33: 119-127.

Lowry, P.H., N.J. Rosenbrough, A.L. Farr and R.J. Randall. - 1951. Protein measurement with a Folin phenol reagent. J. Biol. Chem., 193: 265-275

Menzel, D.W. and J.H. Ryther. - 1960. The annual cycle of prima- ry production in the Sargasso Sea off Bermuda. Deep-Sea Res., 6: $351-367$.

Montero, M.F. - 1993. Respiración y actividad ETS en microplancton marino. Variabilidad del ETS en aguas de Canarias. Ph.D. thesis, Univ. Las Palmas de Gran Canaria, 194 pp.

Ojeda, A. - 1998. Dinoflagelados de Canarias. Estudio taxonómico y ecológico. Ph.D. thesis, Univ. Las Palmas de Gran Canaria, $436 \mathrm{pp}$.

Owen, R.W. and B. Zeitzschel. - 1970. Phytoplankton production: Seasonal changes in the oceanic eastern tropical Pacific. Mar. Biol., 7: 32-36.

Packard, T.T. - 1969. The estimation of the oxygen utilisation rate in seawater from the activity of the respiratory Electron Transport System in plankton. Ph.D. thesis. Univ. Washington, Seattle, $115 \mathrm{pp}$.

Parsons, T.R., Y. Maita and C.M. Lalli. - 1984. A manual of chemical and biological methods for seawater analysis. Pergamon Press, New York, 173 pp.

Purdie, D.A. - 1996. Marine phytoplankton blooms. In: C.P. Summerhayes and S.A. Thorpe (eds.), Oceanography. An Illustrated Guide, pp. 89-95. Manson Publ., London.

Sournia, A. - 1969. Cycle annuel du phytoplankton et de la production primaire dans les mers tropicaux. Mar. Biol., 3: 287303.

Steeman-Nielsen, E. - 1952. The use of radio-active carbon $\left({ }^{14} \mathrm{C}\right)$ for measuring organic production in the sea. J. Cons. Int. Expl. Mer, 18: 117-140.

Sverdrup, H.U. - 1953. On conditions for the vernal blooming of phytoplankton. J. Cons. Int. Expl. Mer, 18: 287-295.

Unesco. - 1968. Zooplankton sampling. Monography of oceanographical methods. 2: 1-174

Verity, P.G., G.A. Paffenhöfer, D. Wallace, E. Sherr and B. Sherr. - 1996. Composition and biomass of plankton in spring in Cape Hatteras shelf, with implications for carbon flux. Cont. Shelf Res., 16: 1087-1116. 